Article

\title{
Humanitarianism as Politics: Civil Support Initiatives for Migrants in Milan's Hub
}

\author{
Giulia Sinatti \\ Department of Social and Cultural Anthropology, Vrije Universiteit Amsterdam, 1081 HV Amsterdam, The Netherlands; \\ E-Mail: g.sinatti@vu.nl
}

Submitted: 15 January 2019 | Accepted: 12 March 2019 | Published: 27 June 2019

\begin{abstract}
Humanitarianism is increasingly used to address migration in Europe, from search and rescue operations at sea to reception on land. Scholars often interpret humanitarianism as a means for states to depoliticize migration and prioritize securitization. In this article, I analyze perspectives on humanitarianism among civil society volunteers and workers who, alongside institutions, deliver humanitarian support to migrants. Civil initiatives in this field by independent volunteers, non-governmental organizations and charities have surged, thus shifting tasks traditionally under the responsibility of the state to non-state actors. Based on ethnographic fieldwork in and around the premises of the Hub (a center providing humanitarian assistance to migrants transiting in the Italian city of Milan), I show that engaging in such civil support initiatives raises the levels of political awareness and activism among ordinary citizens. Through insight into the daily actions, motivations and aims of the men and women operating at the Hub, I show that their involvement in humanitarian assistance marks the beginning of a personal journey in which they gradually conceive what they do as far from being in support of depoliticizing state securitization policies and rather as politically loaded.
\end{abstract}

\section{Keywords}

civil society; depoliticization; humanitarianism; migration; repoliticization

\section{Issue}

This article is part of the issue "The European Refugee Controversy: Civil Solidarity, Cultural Imaginaries and Political Change", edited by Gert Verschraegen (University of Antwerp, Belgium) and Robin Vandevoordt (University of Oxford, UK/University of Antwerp, Belgium).

(C) 2019 by the author; licensee Cogitatio (Lisbon, Portugal). This article is licensed under a Creative Commons Attribution 4.0 International License (CC BY).

\section{Introduction}

In 2015, almost 1,015,000 people entered Europe via the Mediterranean (United Nations High Commissioner for Refugees [UNHCR], n.d.). In the same year, over $1,220,000$ asylum applications were filed in the continent, followed by almost 1,195,000 in 2016 (Eurostat, n.d.). At this time, humanitarian initiatives multiplied supporting migrants along the external borders of Europe and at key transit or arrival nodes within the continent.

Scholars propose a critical reading of humanitarian assistance to migrants, indicating that states use it to downplay a political problem to a sheer humanitarian issue. I recognize the value of this interpretation, while pointing at two limitations. First, the literature empha- sizes institutional recourse to humanitarianism. Second, it adopts a reductive definition of humanitarianism as life-saving relief, which downplays ethical and political dimensions inherent in humanitarian work on the ground. I further illustrate both points next.

Discussions about the links between humanitarianism and politics are situated in scholarly work about governance, which interprets humanitarian assistance as complicit with state-driven aims to securitize Fortress Europe (Pécoud, 2015). Watson (2011) suggests that humanitarianism is a sector of securitization: both justify the adoption of emergency measures by defining issues as threats. According to Italian philosopher Agamben (1998), the separation between politics and humanitarianism is paradigmatic in the case of the refugee. In refugee camps, a state of exception prevails in which 
bare life-the mere biological aspect of life addressed by humanitarian assistance-is prioritized over other aspects of life-life as it is lived. This dehumanizing strategy strips migration and refuge of their political dimension. By emphasizing the urge for life-saving measures that protect bare life and downplaying the role of nationstates, the refugee camp moves out of the political field and epitomizes the raise of what Foucault (2008) calls biopolitics.

Several scholars have drawn on the arguments above to highlight the a-political or depoliticizing effects of humanitarianism when used in the migration field. Malkki (1996) proposes that a focus on suffering abstracts people from historical and structural contexts, thus depoliticizing their condition. Ticktin's $(2006,2011)$ analysis of humanitarianism and immigration law in France shows that care and compassion offer protection to people suffering from bodily vulnerability, so that "once one is...protected by humanitarian clauses, one loses one's political and social rights" (Ticktin, 2006, p. 44). Fassin (2005) talks of "compassionate repression" to illustrate how transforming asylum into an issue of moral sympathy diverts attention from the political aspect of asylum claims.

In the interpretations just outlined, humanitarianism is conceived as a state-driven affair. Agamben understands political agency at the level of sovereign states. Similarly, Malkki (1996), Ticktin $(2006,2011)$ and Fassin (2005) foreground institutional recourse to humanitarianism. This overlooks the involvement of non-state actors, despite civil society occupying a significant role in the migration field, including in humanitarian assistance (Cuttitta, 2018; Garkisch, Heidingsfelder, \& Beckmann, 2017). Throughout Europe, civil support initiatives by non-governmental organizations (NGOs), charities, human rights organizations, grassroots associations and independent volunteers offer first help (e.g., distributing food and clothing, offering shelter and medical aid) to newcomers in ports of disembarkation, temporary camps and transit nodes. I argue that including attention to these initiatives adds complexity to how the relationship between humanitarianism and politics is interpreted.

The emphasis on institutional recourse to humanitarianism leads to a second limitation of the abovementioned literature, which reduces humanitarianism to life-saving relief. Yet this overlooks essential scholarship about the practices of humanitarian organizations on the ground. The latter indicates that humanitarianism involves more than its basic definition, i.e., "the provision of relief to victims of human-made and natural disasters" guided by principles of neutrality, impartiality, and independence (Barnett \& Weiss, 2008, p. 3). In the field, through reflection on its core values, humanitarianism may also extend to broader objectives such as human rights, democracy promotion, development, and peacebuilding (Barnett \& Weiss, 2008). In this sense, it is constantly enmeshed with moral dilemmas (Finnemore,
2008) and far from depoliticizing. Rather, it engages in what Fassin (2007) calls "politics of life": it evaluates human beings and the meaning of their existence. In his words: "a common interpretation...tends to distinguish and to contrast politics and humanitarianism, declaring that the latter is gradually replacing the former or even announcing the advent of humanitarianism and the end of politics" whereas "everything suggests that rather than become separate, humanitarianism and politics are tending to merge" (Fassin, 2007, pp. 508-509).

Emerging empirical literature about civil society involvement in humanitarian responses to migration convenes that humanitarianism and politics may indeed be entangled. This is documented, for instance, in Cuttitta's (2018) analysis of NGOs undertaking search and rescue operations in the Mediterranean. They conceive their activities not merely as saving migrant lives, but as a commitment to turn the sea "into a political stage from which they can make their voice heard" (Cuttitta, 2018, p. 641) and challenge institutional policies and practices through lobbying and advocacy. In a similar vein, Youkhana and Sutter (2017) point at political contestation by pro-migration activist movements. With evidence from the spontaneous camp of Calais in France, Sandri (2018) qualifies informal "volunteer humanitarianism" as an open form of protest against institutional border securitization practices that establishes a connection between humanitarianism and activism. These authors convene that civil society humanitarianism in the migration field goes hand in hand with politics. Politics is understood, here, along the lines of French philosopher Jacques Rancière (1999), who considers political action as expressing disagreement and aspiring to change an existing social order. Rancière introduces a distinction between 'politics' - which challenges the order of things through disagreement-and 'policing'-which refers to the rules that govern the disciplining of bodies (Rancière, 1999, p. 29). Institutional recourse to humanitarianism to manage migration is a form of policing: a means to securitize, exercise control over and depoliticize migration. Political, instead, are attempts to challenge the underlying rules. Accordingly, the respondents of Cuttitta (2018), Youkhana and Sutter (2017) and Sandri (2018) engage in politics by expressing dissent through forms of antiinstitutional protest such as lobbying, advocacy or public demonstration. These forms of protest are traditionally associated with social movements and other organizations pursuing an openly political agenda. Yet literature on humanitarian practice suggests that the latter can be political also in more subtle ways. In Fassin's (2007) politics of life, for instance, attributing value to human lives is sufficient to qualify humanitarianism as political.

In this article I further investigate the links between humanitarianism and politics beyond the explicitly political actions of NGOs and activist movements. Recognizing the variety of civil support initiatives in this field, I focus on how the everyday activities of the many private, self-governed, non-profit organizations and infor- 
mal activities that see many ordinary citizens engage for the benefit of migrants may also be political. My respondents consist of the men and women providing humanitarian support and engaging as professionals, casual laborers or volunteers connected to established NGOs and charities, associated with informal grassroots initiatives, or operating independently. The questions I raise are whether and how humanitarian support offered through these civil initiatives is instrumental to policing or, instead, political. Do civil volunteers and workers reinforce and support depoliticization by filling an institutional gap? Or do they repoliticize migration by disagreeing with state perspectives?

I answer these questions with evidence from civil initiatives delivering humanitarian support to migrants in the city of Milan. In the next section, I describe these initiatives and review my research methods. Two analytical sections follow, in which I illustrate ways in which civil humanitarian support may be interpreted as political. First, I examine the actions of volunteers and workers, arguing that they do more than care for migrants' life-saving needs. In an attempt to address migrants as dignified subjects, they are political in largely involuntary ways as they strive to pursue humanitarianism in the sense of Fassin's (2007) politics of life. Second, I illustrate how initial involvement leads many volunteers and workers to become further committed to making a difference and how they use humanitarianism to express disagreement with institutional perspectives (Rancière, 1999). I also highlight that these expressions of disagreement stem from deliberate political awareness yet may be expressed in silent ways and do not necessarily lead to explicit public protest. Lastly, I offer some conclusions in a closing section.

\section{The Hub at the Core of Migrant Routes}

Italy is a country of first entry for migrants into Europe. After peak arrivals in 2015, a report by the UNHCR showed that, at the end of June 2017, more than 200,000 migrants and refugees were in reception centers in Italy, despite two thirds of new arrivals continuing their journeys to further European destinations (UNHCR, 2017).

These figures imply that humanitarian aid for migrants is highly relevant in Italy. This is evident not only in ports of disembarkation in the south, but also in other localities along migrants' routes to northern Europe, such as Milan. Official data from the Municipality indicates that 125,500 migrants were assisted between 2013 and 2017 in the city's official reception centers, alongside an inestimable number of migrants cared for unofficially.

At a national level, Italian policy and practice address migrant arrivals as an emergency issue (Campomori \& Caponio, 2014; Marchetti, 2014). In border locations like the island of Lampedusa and other ports of first disembarkation, humanitarian responses are institutionallydriven and highly securitized (Tazzioli \& Garelli, 2018). In Milan, civil initiatives providing humanitarian support to migrants surged in 2013. The news of two consecutive migrant shipwrecks in Lampedusa dominated the Italian media and hundreds of survived migrants camped at the city's main rail station, the Stazione Centrale. Migrants carried visible signs of having endured the sea crossing. Despite autumn weather, they bore no or few belongings, wore plastic thong sandals or were barefooted. Their clothes were stained with brine and some carried the shiny thermal blanket received during the sea rescue. Some suffered from hypothermia, were physically injured or in distress. Witnessing this scene on their doorstep, people spontaneously mobilized to distribute food, blankets and clothing.

Building on these spontaneous responses, Milan's municipal authorities established the Hub in purposely refurbished premises under the elevated rails of the Stazione Centrale. The Hub dealt with up to 1,200 migrant arrivals daily, addressing basic needs such as food, shelter and healthcare. It became a well-known reference within informal migrant networks, and many reached Italian soil with its street name scribbled on their arms, or a photo of volunteers or workers in their mobile phones.

The Hub offered a unique setting to gain insight into civil involvement in migrant humanitarianism. In other notable situations in Europe-the spontaneously formed camp in Calais (Sandri, 2018), a public park in Brussels (Vandevoordt \& Verschraegen, 2019) or a squatted hotel in Athens (Rozakou, 2012)-volunteers or activists operated independently and in informal spaces. At the Hub, volunteers and workers from different committees, associations, charities and NGOs worked side by side and under the aegis of institutions: a situation that soon revealed that actions were coordinated, whilst also presenting tensions and overlaps. As a physical site of refugee management, the Hub also became an important space of contestation (della Porta, 2018). For instance, smaller initiatives refrained from involvement at the Hub, in opposition with the philosophy of larger organizations or with the official approach of municipal authorities.

These tensions called for an investigation of the logics underlying humanitarian support and of the motivations urging volunteers and workers to act. I achieved this through ethnographic fieldwork, including participant observation, online research and interviews with respondents (whose names I have anonymized). During multiple field visits between 2013 and 2017, I spent the equivalent of sixty full-time days observing respondents as they dispensed humanitarian support to migrants and the daily interactions between volunteers and workers. In this time, I also attended meetings, public events and protests in and around the Hub. In between field visits, I followed respondents' social media activity: I noted how they chose to represent what they did and recorded posts that triggered animated streams of comments. When conducting supplementary interviews with twenty respondents, I used these social media posts as elicitations, inviting them to reflect about underlying meanings and values. Taken as a whole, this ethno- 
graphic data provides insight into what prompted volunteers and workers to engage in humanitarian support to migrants, how they conceived what they did and what they (hoped to) contribute to.

\section{From Minimalist to Enabling Humanitarianism: Involuntary Politics of Life}

The Hub was operational for over three years, yet activities always remained characterized as temporary measures, adapting to seasonal fluctuations in the numbers and composition of incoming migrants. This approach follows a logic that is in line with Italian national institutional framings of migrant arrivals as an emergency issue (Campomori \& Caponio, 2014; Marchetti, 2014) and temporarily addresses only the superficial consequencesthe threats to bare life-of a deeper structural problem. Civil support initiatives at the Hub were funded through short-term tendered contracts with municipal authorities, in which the mandate was to cater for migrants' basic needs.

This form of humanitarianism is easily associated with the official approach of institutions, to which larger civil society organizations may adhere (or instrumentally adapt). The slogan of one charity operating at the Hub recited: "First Help, Always". This message indicates that the organization is faithful to the core ethic of humanitarian intervention: saving lives. Actions are presented as "based on the satisfaction of offering unconditionally, to a person in danger of dying, the aid which enables him to survive" (Fassin, 2007, p. 510). Civil society organizations use this biopolitical bureaucratic logic strategically in their official discourse, drawing "on a global assemblage of categories, legal definitions, norms and standards, and procedures and technologies associated with humanitarian aid" (Robins, 2009, p. 638). They adopt what Redfield (2005) defines "minimalist biopolitics", focusing on basic needs such as medical aid, shelter and food relief. The everyday motivations and actions of the volunteers and workers ensuring that those humanitarian goals were met, however, reflected alternative preoccupations.

Some respondents indeed conceived humanitarian assistance as a means to protect bare life. When I shadowed them, some referred to migrants as "gli ultimi" (the last). From their words, the image emerged of a mass of helpless, de-humanized people who have nothing and are in desperate need to receive. A volunteer doctor insisted that she was moved to act by humanitarian motives and reinforced her argument claiming that her best gratifications came not from the Hub, but from the times she spent on board Italian Naval ships rescuing migrants at sea:

The most beautiful work for a doctor is on board ships. There the line between life and death is a question of seconds. Either you save them, or they die. It is a very powerful challenge. If you are born to heal, it doesn't get more extreme than this. (Cosima)
Some acknowledged that their role as humanitarians included also a controlling dimension, one that-following Rancière-is associated with policing. A charity worker commented about the registration procedure for $\mathrm{mi}-$ grants at the Hub: "At the registration desk, my role is first of all to understand whether the person sitting in front of me is a real refugee or not" (Amun). Amun recalled the episode of a Somali who stood in the queue for the stamps giving access to food, a set of new clothing and a bed for the night. When his turn arrived:

He didn't look like someone who's just arrived. His clothing didn't give that away. Even the smell of a refugee, when someone hasn't washed for a few days...various signs tell you whether someone is a refugee. So I said to him: "You're not a refugee. Empty your pockets and show me something, anything that proves that you're a refugee". A train ticket from Taranto saying he'd just disembarked and come to Milan, whatever....And as he emptied his rucksack, he dropped an Italian passport. That Somali was an Italian citizen. So I said to him: "Sorry, we can't welcome you".

Amun explained that he used the term 'refugee' to refer broadly to migrants in distress, having just arrived illegally in Italy and regardless of whether they had applied for asylum in Italy or intended to do so. A perceived need for immediate and temporary basic support, in Amun's eyes, was the main precondition qualifying migrants for humanitarian support. Like Cosima and Amun other respondents expressed their role as one in which they, as humanitarians, protected bare life whilst also occupying a position of power and control over migrants. At a first reading, this appears to reinforce the dehumanizing and depoliticizing side of humanitarianism.

A closer look, however, uncovers that many workers were ill at ease with 'policing' tasks attached to their roles. When talking about what they did, they challenged the idea of humanitarianism as ending with the protection of bare life. When justifying their actions, many chose words like 'solidarity', 'philanthropy', 'justice', 'humanity', 'empathy', and 'equality'.

More than words, however, it was the actions of volunteers and workers that questioned the minimalist biopolitics (Redfield, 2005) of "holding people in a position of continuous need for assistance" (Michele). Despite being aware of power imbalances between themselves as humanitarian givers and migrants as aid recipients, many maneuvered within the system to do more than dispense basic aid. They aspired to be facilitators, enabling migrants to find their own way. Patrizia explained how workers or volunteers circumvented minimalist humanitarian logics:

[At the Hub, migrants] are subject to our rules, to the food we give them. Their autonomy is equal to zero. They even need to knock on the door and ask me for toilet paper: we don't have enough for everyone, so 
I have to ration it. We use the word 'guests' to indicate migrants and here this word is a good fit. To call someone a guest is depriving him of responsibility. Here people are deprived of responsibility and they are treated accordingly.... You are a guest and you follow my rules. Now, though, we have started imagining paths for these people, but this comes out of the initiative of those working here. For instance, I may know some migrant youths who like playing football and I may know of a football initiative in the neighborhood, so I go and tell them. This is not in the workers' vademecum, though. If anything, the vademecum says "manage fights, deal with registration, give them a bed and that's it". (Patrizia)

Volunteers and workers instigated a range of sociocultural activities: language classes, recreational activities for children, sport events, city tours, or pairing migrants with sponsor families. These initiatives had a central concern not for basic needs, but for social fulfilment. They showed that humanitarian action can move "from bare life to qualified life, from physical survival to social existence" (Fassin, 2007, p. 518).

Respondents addressed migrants beyond bare life through socio-cultural activities as well as in more subtle ways. They encouraged migrants to take direct responsibility in the everyday delivery of humanitarian aid: serving food at the canteen or unfolding and storing the camp-beds that were set up every night in the communal dormitory. Respondents conceived involvement in these moments as a chance for migrants to step out of the category of guest or victim attributed to them through depoliticizing minimalist humanitarian logics. Some volunteers and workers went to great lengths to address migrants by their name, to give an otherwise ephemeral interaction a deeper significance. Against the reading of humanitarianism as de-historicizing (Malkki, 1996), I interpret these efforts as striving to inject personal biographies back into the generalized figure of a migrant victim. Informal support to migrants extended to advice about administrative and legal dealings with asylum procedures or border-crossings, with the intention of supporting migrants to make independent, informed choices about their future.

I do not evaluate whether the actions just illustrated had an empowering effect on migrants, nor how migrants themselves received them. What is noteworthy is that the intention behind these actions contrasted sharply with the depoliticizing logics of minimalist humanitarianism. In their daily actions, volunteers and workers put forward a politics of life (Fassin, 2007) that attempted to value victims beyond basic needs. My findings resonate with Rozakou's (2012) analysis of humanitarian initiatives assisting migrants in Athens. She concludes that, through the practices of volunteers operating outside formal reception camps, refugees may also be "reconstituted as political subjects" (Rozakou, 2012, p. 573).
So far, I have uncovered tensions between the logics of respondents delivering humanitarian support in civil initiatives on the one hand and the official logics of institutions on the other hand: while the latter emphasize saving lives, the former stress the importance of every life and move beyond basic needs. These divergent views led volunteers to speak with nostalgia about the times before the Hub was established, cherishing the freedom with which they had been able to approach and assist migrants. The same sentiment induced some initiatives to remain independent from the Hub, operating informally on the streets and in disagreement with minimalist biopolitics (Redfield, 2005). As one respondent put it: "volunteering is a positive action that should enable a refugee or asylum seeker to engage independently on a journey of inclusion" (Antonio).

In this section, I have shown that the men and women delivering support in a system conceived as responding to basic migrant needs may be inspired by alternative humanitarian logics. Respondents spoke of migrants and refugees as the ultimate vulnerable others whose bare life should be protected: these arguments indeed resonate with the depoliticizing or a-political traits denounced by scholarship on migrant humanitarianism. Respondents however also strived to treat migrants as dignified people in need to make their way, autonomously. In this sense, they pursued another humanitarianism: one that promotes a politics of life (Fassin, 2007) by moving beyond mere survival and committing to concerns for human dignity. My data identify tensions inherent in humanitarianism. One logic focuses on protecting migrants' bare life: I call this minimalist humanitarianism. An alternative logic hopes to empower migrants and facilitate their autonomous agency: I call this enabling humanitarianism.

People delivering support to migrants at the Hub experienced tensions between minimalist and enabling humanitarianism, as each is "defined by different configurations of practices, principles, and understandings of the proper relationship between politics and humanitarianism" (Barnett \& Weiss, 2008, p. 5). Many volunteers and workers were inspired by enabling humanitarianism and attempted to inject human value into the migrants they assisted. They often did so, however, inadvertently and without being aware of the political value of their thoughts and actions: they engaged in politics of life, yet involuntarily. Vandevoordt and Verschraegen (2019, p. 102) found the same among civil humanitarians in Brussels whose "political intentions were far from self-evident" and who, for instance when establishing horizontal relations with refugees, were unknowingly political. My data show the value of integrating a focus on the exclusionary logics of states' humanitarian responses with a focus on volunteers and workers in civil support initiatives who may counteract them (Larruina \& Ghorashi, 2016). In the next section, I discuss how this counteraction may become loaded with greater political awareness. 


\section{Humanitarianism as Politics: Engaging in Silent Disagreement}

Many respondents became involved in humanitarian support through volunteering, dedicating a few hours to assisting (often in the minimalist humanitarian sense) migrants and refugees. This exposed them to emotionally intense experiences, followed by personal involvement in the stories of individual migrants.

On social media, respondents maintained contact for years with migrants and refugees met at the Hub. Lorenza, one of the first volunteers assisting Syrians since before the Hub was established, recalled:

We used to go every morning and offer bread and Nutella to Syrian refugees....From there we took a further step and started talking to them....Clearly their stories affected us. Speaking with them was the most beautiful thing that this initial group did. It created a bridge, a human bond that went beyond the fact of offering bread with chocolate spread and a warm cup of tea. (Lorenza)

The fleeting moment of humanitarian giving led to deeper contact. Shifting from minimalist to empowering humanitarianism, some felt invested with an overwhelming sense of personal responsibility:

Some ask you "Where do you think I should go? Where should I migrate to?" This is a huge responsibility....When people ask you where they should spend the rest of their lives, this is not a question you can answer lightly. (Sarah)

Conversation after conversation, interview after interview, I became aware of how respondents were affected by migrant stories. As a researcher, I was interested in the experiences of volunteers and workers-not of migrants. Yet whenever I gave interlocutors leeway, they would steer the discussion towards excruciating details of painful migrant stories. Anna, a volunteer who housed migrants in her home when the Hub reached full capacity, recalled the time she was sitting on the couch of her Milanese apartment when a migrant recognized himself in the images of a report about a sea rescue aired on the evening news. While she watched history unfold on the television screen, she felt she could reach out and touch it in the person sitting next to her in the private space of her home.

Exposed to the suffering of otherwise distant others, Anna and other respondents reinjected personal histories into migrant subjects. Many looked at their own lives in a new light and reported personal growth. Against a perceived wave of raising European populism and individualism, they read the human and social situations of migrants within an international geo-political vision, became skeptical about institutional responses, and nurtured the ambition to do more than help people in distress.
I observed a correlation between growing personal involvement in enabling humanitarianism and a conscious politicized commitment. As with Ayana, a secondgeneration Eritrean supporting co-nationals escaping the current regime in the streets of her neighbourhood, which hosts a historically established Habesha community:

I'd never been an activist before, I never supported any cause. I'd also always been distant from lay or religious associations. But engaging in migrant assistance took me on a long, introspective journey that could only lead me to engage further and learn to relate with and challenge institutions. (Ayana)

For many, political engagement began with critique of the Hub itself, where I observed tensions between minimalist and empowering humanitarianism. Some openly criticized the conditions under which help was delivered, denouncing that the Hub allowed only fleeting encounters. As Lorenza underlined: "You cannot talk to all of them.... The Hub doesn't give you time..... In transit, you don't have time to relate to one another". Respondents would mock the slogan "First Help, Always": "First help and no more", they would add, voicing disapproval of a rationality that reduces victims to basic needs, to bare life. Whether the charity in question is indeed associated with depoliticization is a judgement beyond the scope of this article. I did however record that, by supplementing institutional funding with private donations, the organization enjoyed flexibility on the ground allowing workers to go beyond what was requested in binding contracts with local authorities. For example, if the mandate limited provision of shelter to migrants of certain nationalities, respondents could open the doors to other migrants. In this sense, the charity prudently avoided explicit political confrontation with its institutional donors. It also closed a blind eye to what respondents did on the ground, leaving it to their discretion to solve tensions and ambiguities that are typical of humanitarian organizations: instrumentally complying with a depoliticizing concern for human survival, whilst ethically striving for a concern for human dignity (Redfield, 2005). This way, bending the rules became a silent but deliberate expression of political dissent by workers or volunteers.

For those who understood the expression of dissent as requiring more open forms of political protest, the Hub hindered the pursuit of their aims. They chose to operate independently in the informal spaces of streets, squares and public parks surrounding the Stazione Centrale. Besides delivering support to migrants, they also engaged in outspoken forms of dissent. They raised public awareness, for instance holding talks in schools. They initiated public protests and denounced institutions for reducing migrants to mere, dehumanized numbers. The reasons leading some to shift to such overtly politicized engagement were usually tied to personal background and lived experience. For instance, an activist operating 
outside the Hub compared his own choice as a secondgeneration migrant with that of first-generation migrants for whom social work for a large charity had become a regular job:

I believe in people's autonomy and this is tied to a personal baggage of claims I make to the society I live in. Others [who have recently immigrated] have a more subaltern relationship with Italian authorities. We have strong disagreements on this point. This is why many second-generation migrants experienced working at the Hub as a learning opportunity, but then decided to leave. Whereas [recent immigrants] decided to stay on in a role that can contribute little to changing the status quo. (Awet)

Political action, however, was not restricted to independent initiatives such as those just described. Also within the Hub, workers disagreeing with the official Hub logic of saving lives carried out political actions from within. They were not so much critical of the approach of the charities and NGOs operating at the Hub. Rather, they held institutions responsible for a situation that, as Amun suggested, "aims at quantity, not quality". They critiqued the Italian state for preferring solutions that address an out-of-the-ordinary situation to structural solutions (Campomori \& Caponio, 2014; Marchetti, 2014). According to Patrizia, "the Hub treats migrant flows as an emergency issue, whereas it is a structural phenomenon. To put a plaster on a war wound doesn't make sense". Insight into the failings and contradictions of how migration is governed led some respondents to deliver humanitarian support while simultaneously questioning it and critiquing institutional mechanisms through moral and political pressure:

If one is just a volunteer it means that in a totally spontaneous way he or she is engaging in activities. These may follow ethical and moral motivations, but once the activity is done it ends there. Activism, instead, is engaging in an activity but also pushing your idea further and instigating it. One thing is to say "I help migrants to write their CV": this is volunteering. Another thing is to say "I open a desk to support migrants in looking for work and I talk with institutions, express people's discontent, propose alternatives": this is activism. They are two very distinct things. (Patrizia)

When I asked Patrizia for an example of how she exercised activism as charity worker, she replied that the data about migrants sheltered at the Hub that she transmitted weekly to the Municipality were her main channel for protest. She collected and organized the information to highlight the growing number of migrants being returned to Italy from other European countries on the grounds of the Dublin Regulation. This way, she deliberately made authorities aware of new migrant vulnerabilities emerging out of European regulations, putting pressure on them to deal with this reality. She also gathered figures highlighting the presence, at the Hub, of migrants officially considered highly vulnerable (e.g., pregnant women) and eligible for support in dedicated centers, thus exposing institutional failure in meeting the requirements of international protection standards. Chiara, another charity worker, daily escorted to the offices of the Municipality a group of unaccompanied minor migrants who hung around the Hub during daytime but were not officially admitted to sleep there at night because entitled to supplementary protection. Due to infrastructural lack of capacity in centers assisting minors travelling alone, these children joined the ranks of those sleeping rough around the Stazione Centrale.

When humanitarianism takes on a political connotation-not just a depoliticizing one-questioning the accepted ways in which assistance is delivered becomes an integral part of practicing humanitarianism. Outside the Hub, independent activists challenged the dehumanizing logics of humanitarianism by engaging in open protest or promoting public advocacy. Even inside the Hub, Patrizia and Chiara engaged in deliberate, yet silent expressions of dissent. Their strategies recall the "imperceptible politics" used by illegalized migrants to struggle for work and unionization described by Wilcke (2018). They show that being political does not necessarily require engaging in visible public protest. By reminding local authorities that it should be their responsibility to provide appropriate shelter for unaccompanied migrant minors, Chiara took on a role of watchdog; by making institutions aware of the shifting composition of migrants in need, Patrizia tried to exercise on them political pressure.

At the Hub and independently, the actions of volunteers and workers suggest that involvement in assistance to newcomer migrants was, for some, a means to restore a conscious political role for humanitarianism by "revealing and reviving the political (that is the plural and conflictual) character of politics" (Cuttitta, 2018 , p. 635 , emphasis in original) and repoliticize the migration field. Without necessarily engaging in overt forms of public protest, in the examples presented here, civil society actors nonetheless still engaged in actions that meet Rancière's (1999) definition of political: they silently challenged the minimalist humanitarian logics of institutional approaches.

\section{Conclusion}

The European migration 'crisis' brought to the fore emerging subjects from civil society in the field of humanitarianism (Sezgin \& Dijkzeul, 2016). As I have shown in this article, it also led to contesting some of humanitarianism's basic principles. Civil initiatives of humanitarian support reveal tensions between depoliticization and repoliticization.

I acknowledge the worth of critical approaches to humanitarianism that emphasize its depoliticizing value. However, I also show that an exclusive focus on hu- 
manitarianism as an institutional logic conceals the profoundly political nature embedded in humanitarian work on the ground. As broader literature on humanitarianism has indicated, humanitarian actions constantly grapple with moral and ethical dilemmas that make them deeply political. I thus highlight the limitations of the biopolitical paradigm that "can obscure the complexity of actual practices and the diversity of aid" (Rozakou, 2012, p. 565). I do so by integrating an analysis of institutional uses of humanitarianism in migration management with an analysis of the practices and underlying motivations of civil initiatives of humanitarian support. This allows revealing particular styles and strategies that civil initiatives of migrant support bring to responses to migration, reflecting a diversity of ways in which humanitarianism is conceived, practiced, and linked to politics.

Actions of people on the ground indeed contribute to depoliticization when they uncritically support the official system of migrant reception. Their actions, however, also prove political in at least two ways.

First, in the relationship between civil society volunteers or workers and their migrant beneficiaries, I have distinguished between a minimalist humanitarianism that is exclusionary and depoliticizing and an enabling humanitarianism that questions an exclusive emphasis on bare life. While the former indeed contributes to depoliticizing migration, the latter is repoliticizing. Volunteers and workers put into practice an understanding of humanitarian aid that evaluates the human dignity of beneficiaries. Instead of drawing on minimalist humanitarian principles to prioritize security and sovereignty, they prioritized migrants' rights and well-being. In this sense, civil society initiatives of humanitarian support engaged in a politics of life (Fassin, 2007) that aspired to enact an alternative social order. While not necessarily voicing disagreement with established ways of doing humanitarianism, the experiences and practices of volunteers and workers did nonetheless constitute involuntary politics, offering fertile ground for more overt and conscious forms of political engagement to develop.

Second, when the initiatives of volunteers and workers take on a denouncing role-by calling attention to a gap, rather than just filling it-humanitarianism becomes consciously political. Following Rancière's (1999) definition, humanitarianism is a means to express disagreement and antagonize the configurations of institutional approaches to migration. Humanitarianism, in this sense, is "deployed among the weak as it denounces the powerful" (Fassin, 2007, p. 511). Most interestingly, this form of political action need not rely on open public protest through demonstrations or public advocacy. Many expressed it silently, through everyday practices that challenged institutional categorizations of migrant needs (e.g., when extending humanitarian assistance to those considered ineligible by institutions or denouncing to authorities the neglect of their own responsibilities).

The examples presented in this article show that civil society actors involved in humanitarian support to mi- grants are far from passively filling an institutional gap and acting in support of state securitization strategies. Rather, through direct involvement in humanitarianism, ordinary citizens become conscious of its inherent tensions, which leads their political awareness and engagement to grow. As they struggle to come to terms with the ethics of life-saving only approaches, some reinject value in migrant lives and, by doing so, engage in involuntary politics. For others, progressive involvement comes with increasing awareness of the political value of their thoughts and actions, leading to open or silent expressions of political dissent.

At a time when humanitarianism has been indicated as being void of political value, volunteers and workers in civil support initiatives question the minimalist logics of humanitarianism as bare life. By re-humanizing the ways in which aid is delivered on the ground, giving voice to global inequalities and injustice, acting as watchdogs and questioning institutions they repoliticize the migration field. Ultimately, by contrasting an institutional and a civil perspective on humanitarian support to migrants, I show that a plurality of humanitarian traditions coexists in this field, with different political voices.

My findings also testify the increasing entanglement, in current responses to migration, between institutional actors, development and relief organizations, charities, volunteers, activists and social movements. The fact that all of these have become essential actors in this field has important implications for migration policy and politics in general. The interactions and frictions between these actors, in fact, become the cogwheels through which underlying ethics and responsibilities are interrogated. This interrogation, I argue, may be not only a source of contestation, but could also constitute a motor through which change to current migration systems may emerge democratically.

\section{Acknowledgments}

I wish to thank Margit Feischmidt for her inspiring comments on an earlier draft of this article, as well as the editors of this thematic issue and the anonymous reviewers for their feedback. My gratitude goes to those who opened the doors of the Hub to me, giving me insight into their lives, their hearts, the beauties and many contradictions of the world in which they operate. Lastly, a special thanks to Claudio, for making me come back home.

\section{Conflict of Interests}

The author declares no conflict of interests.

\section{References}

Agamben, G. (1998). Homo sacer: Sovereign power and bare life. Stanford, CA: Stanford University Press.

Barnett, M., \& Weiss, T. G. (2008). Humanitarianism: A brief history of the present. In T. G. Weiss \& M. 
Barnett (Eds.), Humanitarianism in question: Politics, power, ethics (pp. 1-48). Ithaca, NY: Cornell University Press.

Campomori, F., \& Caponio, T. (2014). Migrant reception policies in a multilevel system: Framing and implementation structures in the Italian regions. In E. Hepburn \& R. Zapata-Barrero (Eds.), The politics of immigration in multi-level states (pp. 130-149). New York, NY: Palgrave Macmillan.

Cuttitta, P. (2018). Repoliticization through search and rescue? Humanitarian NGOs and migration management in the central Mediterranean. Geopolitics, 23(3), 632-660.

della Porta, D. (Ed.). (2018). Solidarity mobilizations in the 'refugee crisis'. Contentious moves. New York, NY: Palgrave Macmillan.

Eurostat. (n.d.). Asylum and first time asylum applicants-Monthly data. EC Europa. Retrieved from https://ec.europa.eu/eurostat/tgm/refresh TableAction.do?tab=table \&plugin=1\&pcode=tps 00189\&language $=e n$

Fassin, D. (2005). Compassion and repression. The moral economy of immigration policies in France. Cultural Anthropology, 20(3), 362-387.

Fassin, D. (2007). Humanitarianism as a politics of life. Public Culture, 19(3), 499-520.

Finnemore, M. (2008). Paradoxes in humanitarian intervention. In R. M. Price (Ed.), Moral limit and possibility in world politics (pp. 197-224). Cambridge: Cambridge University Press.

Foucault, M. (2008). The birth of biopolitics. Lectures at the College de France, 1978-79. Basingstoke: Palgrave MacMillan.

Garkisch, M., Heidingsfelder, J., \& Beckmann, M. (2017). Third sector organizations and migration: A systematic literature review on the contribution of third sector organizations in view of flight, migration and refugee crises. Voluntas, 28(5), 1839-1880.

Larruina, R., \& Ghorashi, H. (2016). The normality and materiality of the dominant discourse: Voluntary work inside a Dutch asylum seeker center. Journal of Immigrant and Refugee Studies, 14(2), 220-237.

Malkki, L. H. (1996). Speechless emissaries: Refugees, humanitarianism, and dehistoricization. Cultural Anthropology, 11(3), 377-404.

Marchetti, C. (2014). Rifugiati e migranti forzati in Italia. Il pendolo tra 'emergenza' e 'sistema' [Refugees and forced migrants in Italy. A pendulum between 'emergency' and 'system']. Revista Interdisciplinar da Mobilidade Humana, 22(43), 53-70.

Pécoud, A. (2015). Depoliticising migration: Global governance and international migration narratives. Bas- ingstoke: Palgrave Macmillan.

Rancière, J. (1999). Disagreement. Politics and philosophy. Minneapolis, MN: Minneapolis University Press.

Redfield, P. (2005). Doctors, borders, and life in crisis. Cultural Anthropology, 20(3), 328-361.

Robins, S. (2009). Humanitarian aid beyond "bare survival": Social movement responses to xenophobic violence in South Africa. American Ethnologist, 36(4), 637-650.

Rozakou, K. (2012). The biopolitics of hospitality in Greece: Humanitarianism and the management of refugees. American Ethnologist, 39(3), 562-577.

Sandri, E. (2018). 'Volunteer humanitarianism': Volunteers and humanitarian aid in the jungle refugee camp of Calais. Journal of Ethnic and Migration Studies, 44(1), 65-80.

Sezgin, Z., \& Dijkzeul, D. (Eds). (2016). The new humanitarians in international practice: Emerging actors and contested principles. New York, NY: Routledge.

Tazzioli, M., \& Garelli, G. (2018). Containment beyond detention: The hotspot system and disrupted migration movements across Europe. Environment and Planning D Society and Space. https://doi.org/10.1177\% 2F0263775818759335

Ticktin, M. I. (2006). Where ethics and politics meet: The violence of humanitarianism in France. American Ethnologist, 33(1), 33-49.

Ticktin, M. I. (2011). Casualties of care. Immigration and the politics of humanitarianism in France. Berkeley, CA: University of California Press.

United Nations High Commissioner for Refugees. (n.d.). Total arrivals. Unhcr.org. Retrieved from https:// data2.unhcr.org/en/situations/mediterranean

United Nations High Commissioner for Refugees. (2017). Desperate journeys. Refugees and migrants entering and crossing Europe via the Mediterranean and Western Balkans routes. Geneva: UNHCR.

Vandevoordt, R., \& Verschraegen, G. (2019). Subversive humanitarianism and its challenges: Notes on the political ambiguities of civil refugee support. In M. Feischmidt, L. Pries, \& C. Cantat (Eds.), Refugee protection and civil society in Europe (pp. 101-128). New York, NY: Palgrave Macmillan.

Watson, S. (2011). The 'human' as referent object? Humanitarianism as securitization. Security Dialogue, 42(1), 3-20.

Wilcke, H. (2018). Imperceptible politics: Illegalized migrants and their struggles for work and unionization. Social Inclusion, 6(1), 157-165.

Youkhana, E., \& Sutter, O. (2017). Perspectives on the European border regime: Mobilization, contestation and the role of civil society. Social Inclusion, 5(3), 1-6. 


\section{About the Author}

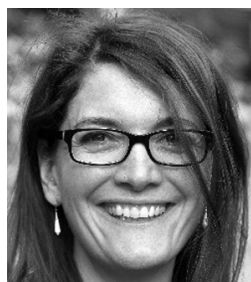

Giulia Sinatti is an ethnographer with a longstanding interest for migration. Her work deals with issues such as migration governance, migration policy, asylum-migration nexus, migration-development nexus, human security, return migration, diaspora and transnationalism, migration between (West) Africa and Europe. On these topics, she has published in recognized journals, including Population Space \& Place, Ethnic and Racial Studies, Ethnicities and African Studies. An engaged scholar, she also advises intergovernmental and United Nations agencies, civil society and grassroots organizations active in the migration field. 